\title{
Klinisch redeneren in het onderwijs aan de Nederlandse medische faculteiten
}

\author{
J.F. Bastiaans, H. de Vries, M. de Haan
}

\section{Samenvatting}

Inleiding: In de basisopleiding tot arts wordt aan alle acht Nederlandse medische faculteiten in toenemende mate aandacht geschonken aan onderwijs in klinisch redeneren. In dit artikel wordt aan de hand van een definitie van klinisch redeneren per faculteit een inventarisatie gepresenteerd van het onderwijs in klinisch redeneren op dit moment.

Methode: Een documentanalyse van studieprogramma's, onderwijsmateriaal en publicaties vormde de basis voor een beschrijving, die voorgelegd werd aan een deskundige van de betreffende faculteit.

Resultaten: De onderwijsprogramma's klinisch redeneren zijn sterk uiteenlopend in ontwikkeling en omvang, waarbij ook de gehanteerde onderwijsvormen en methoden verschillend zijn. Er is grootschalig onderwijs in de vorm van colleges, patiëntendemonstraties en een werkgroep (Groningen). In het kleinschalig onderwijs wordt meestal gewerkt aan de hand van papieren casus. In Nijmegen en Maastricht spelen echte en simulatiepatiënten ook een rol in de kleine groepen. Het aantal studenten in een groep verschilt en als begeleiders fungeren clinici, andere docenten, ouderejaarsstudenten en studenten uit de groep. De onderwerpen zijn overwegend disciplinegebonden. Zij liggen veelal vast in een blauwdruk, al of niet ontleend aan Raamplan 1994.

Beschouwing: De lopende curriculumherzieningen zullen veranderingen betekenen voor het onderwijs in klinisch redeneren. Een interessante vraag is of universiteiten moeten streven naar een gezamenlijk theoretisch en onderwijskundig model voor het klinisch redeneren. Daarnaast is er de vraag hoe vroeg in het curriculum begonnen kan worden met klinisch redeneren. Nauwgezette evaluaties en onderlinge uitwisseling van onderwijsprogramma's, onderwijsmateriaal en toetsvragen zijn wenselijk om tot een goed onderbouwd onderwijsprogramma klinisch redeneren te komen. (Bastiaans JF, Vries $H$ de, Haan $M$ de. Klinisch redeneren in het onderwijs aan de Nederlandse medische faculteiten. Tijdschrift voor Medisch Onderwijs 2002;21(3): 111 -121.)

\section{Inleiding}

Het onderwijzen van basisvakken is waardevol omdat deze kennis nodig is bij het verklaren van klinische fenomenen. Er is evenwel meer nodig om deze kennis om te kunnen zetten tot klinisch bruikbare kennis. ${ }^{1}$ De laatste jaren wordt aan de Nederlandse medische faculteiten in het curriculum in toenemende mate aandacht besteed aan het klinisch redeneren, naast biomedische kennis, attitude en medisch praktische vaardigheden. In Raamplan
1994 en Raamplan 2001 komt het klinisch redeneren aan de orde bij de beschrijving van de algemene eindtermen, waarin onder andere aangegeven wordt langs welke weg het medisch probleemoplossen plaatsvindt. ${ }^{2} 3$ In dit artikel wordt aan de hand van een omschrijving van wat verstaan wordt onder (onderwijs in) klinisch redeneren een overzicht gegeven van de huidige stand van zaken betreffende het onderwijs in klinisch redeneren aan de acht Nederlandse medische faculteiten in 
de eerste vier studiejaren. Ten slotte zal worden aangegeven welke landelijke ontwikkelingen gewenst zijn.

Onderwijs in klinisch redeneren wordt door ons gedefinieerd als 'het onderwijs in het oplossen van medische problemen', waarbij de aandacht gericht is op:

1. het toepassen van evidence-based medische kennis op individuele casus;

2. de procesmatige aanpak van het stellen van een diagnose, waarbij stapsgewijs klinische gegevens geanalyseerd worden, gevolgd door het kiezen van verder beleid en/of uitvoeren van therapie;

3. cognitieve elementen en niet op de psychomotorische vaardigheden.

Deze definitie is een aanscherping van wat in de literatuur hierover verschenen is. ${ }^{14-6}$

Probleemgestuurd onderwijs in kennismodules valt dus buiten onze definitie van onderwijs in klinisch redeneren evenals patiëntendemonstraties die slechts gebruikt worden om ziektebeelden te illustreren. Patiëntendemonstraties die bedoeld zijn om het klinisch denken van de dokter te illustreren, kunnen wel tot het onderwijs in klinisch redeneren gerekend worden.

Klinisch redeneren wordt door velen gezien als een inhoudsspecifieke vaardigheid, die niet tot weinig generaliseerbaar is. ${ }^{4-9}$ Anderen stellen dat er in het onderwijs in klinisch redeneren bij een sterk systematische benadering ook inhoudsonafhankelijke aspecten overgedragen kunnen worden. ${ }^{10}$

\section{Vraagstelling}

De hoofdvraagstelling luidt: 'hoe wordt er momenteel aan de acht Nederlandse medische faculteiten in het onderwijs aandacht besteed aan klinisch redeneren?' Subvragen daarbij zijn:

1. In welke onderwijsonderdelen wordt aandacht besteed aan klinisch redeneren?
2. Hoe worden studenten begeleid en welke methode wordt daarbij gehanteerd?

3. Hoe is de keuze van onderwerpen tot stand gekomen bij het onderwijs in klinisch redeneren?

\section{Methode}

Dit onderzoek is beschrijvend en oriënterend van opzet. Begonnen werd met een documentanalyse van studieprogramma's, onderwijsmateriaal en publicaties. Op basis hiervan hebben de auteurs een beschrijving van het onderwijs in klinisch redeneren aan elke faculteit gemaakt. Per faculteit werden aan een deskundige commentaar of aanvullingen gevraagd.

De co-assistentschappen werden daarbij buiten beschouwing gelaten, evenals het computerondersteund onderwijs (COO) en de toetsing.

\section{Resultaten}

\section{Erasmus Universiteit Rotterdam}

Sinds 1998 kent de Rotterdamse artsopleiding het Klinisch Lijnonderwijs (KLO), met daarin aandacht voor klinisch redeneren. In het eerste studiejaar zijn er wekelijkse patiëntendemonstraties waarin klachten van patiënten worden benaderd vanuit de onderliggende pathofysiologie. In het tweede studiejaar zijn er negentien clusters van drie college-uren ingeroosterd met patiëntendemonstraties waarin patiëntenproblemen geanalyseerd worden. Hierin participeren studenten, na voorbereiding, op actieve wijze. Met ingang van het studiejaar 1998-1999 is binnen het KLO het onderdeel Medisch Probleemoplossend Onderwijs in het derde studiejaar van start gegaan. In groepjes van ongeveer twaalf studenten worden naar aanleiding van een papieren casus patiëntenproblemen geanalyseerd. Centraal hierin staan de training in tech- 
nieken van medische besluitvorming, toepassing van kennis uit voorgaand (blok)onderwijs en stimulering van zelfstudieactiviteiten. De onderwerpen zijn vastgelegd en zodanig gekozen dat de belangrijkste alledaagse klinische problemen aan bod komen. Per bijeenkomst vervult een aantal studenten de functie van referent. Dit wordt apart voorbereid. De groepen worden begeleid door een vaste consulent (clinicus). Vanaf studiejaar 1999-2000 is deze opzet ook in het vierde studiejaar van start gegaan. ${ }^{11} 12$ In september 2001 is in Rotterdam het nieuwe curriculum 'de Erasmus-arts 2007' van start gegaan. Ook hierin zal het klinisch redeneren een belangrijke plaats krijgen.

\section{Katholieke Universiteit Nijmegen}

In het in 1995 vernieuwde curriculumconcept in Nijmegen wordt onderscheid gemaakt tussen het kern- en het keuzecurriculum. In het kerncurriculum ligt de nadruk op de beroepsvoorbereiding tot arts. Daarbij gaat de aandacht naar een theoretische en praktische training in het proces van medisch-wetenschappelijk verantwoorde probleemoplossing. ${ }^{13}$ Klinisch redeneren komt nadrukkelijk aan de orde in twee blokken 'grondslagen en methoden' en in twee blokken 'praktisch klinisch onderwijs' (PKO-1 en PKO-2). In deze blokken wordt, naast communicatietraining en oefening van anamnese en fysische diagnostiek, aandacht gegeven aan de principes van de methodologie van het klinisch analyseren. Dit gebeurt in werkgroepen aan de hand van papieren patiëntencasuïstiek (ongeveer veertien casus), waarbij zelfstudieopdrachten en terugrapportage een belangrijke rol spelen. ${ }^{14}$ De gekozen onderwerpen zijn niet van tevoren vastgelegd. Onderwerpen worden twee keer behandeld, zowel in PKO-1 als in PKO-2, waarbij de moeilijkheidsgraad oploopt en het onderwerp uitgebreider aan de orde komt. De onderwerpen hebben betrekking op het voorafgaande blokonderwijs en betreffen de belangrijkste disciplines. ${ }^{15}$

In het klinisch redeneren staat een expliciet geformuleerde wijze van denken centraal. Deze aanpak wordt aangeduid als de Klinische Probleemanalyse. Uit elke casus worden activerende gegevens gehaald. Al deze gegevens worden vervolgens gegroepeerd tot een lijst van problemen. Daarna wordt per probleem een lijst van hypothesen gemaakt en tot slot wordt per hypothese een diagnostisch of therapeutisch actieplan opgesteld. ${ }^{10} 16$ Deze methode dient vooral om casuïstiek waarin de beelden (nog) niet direct herkend worden langs analytische weg te kunnen oplossen. Men past dit 'methodisch werken' ook toe in de orgaangerichte blokken 'water- en zouthuishouding', 'nieuwvormingen' en 'bewegingsapparaat'. ${ }^{17}$ Overigens wordt ook tijdens de co-assistentschappen bij verschillende specialismen volgens de Klinische Probleemanalyse gewerkt.

\section{Rijksuniversiteit Groningen}

In september 1993 is in Groningen het sterk probleem- en patiëntgeoriënteerde Curriculum 2000 ingevoerd. Daarbinnen is de variatie aan onderwijsvormen groot: patiëntendemonstraties, tutorbijeenkomsten, responsiecolleges, hoorcolleges, werkcolleges/practica en afsluitende 'magistrale' colleges. De nadruk ligt op actieve kennisverwerving van de student en op praktijkgerichte toepassing. ${ }^{18}$ In jaar 3 en 4 wordt in de eerste twee trimesters veel aandacht besteed aan klinisch redeneren. De studenten krijgen daarin 100-200 patiëntencasus voorgelegd, die zij vanuit de gepresenteerde klacht op een probleemgeoriënteerde wijze moeten analyseren. Een werkgroep klinisch redeneren heeft een selectie van onderwerpen 
gemaakt op basis van het Raamplan 1994 en dit ook vastgelegd. ${ }^{19}$ Men werkt geheel volgens 'modelweken', waarin tutorgroepen een centrale plaats innemen. Deze weken beginnen met een patiëntenbespreking, waarin de bij het thema van de week gekozen patiënt wordt gedemonstreerd. Patiënt en bijbehorende studieopdrachten voor de tutorgroepen zijn de directe stimulans voor de student om te gaan studeren. Op de laatste dag van elke week volgen de studenten een 'werkcollege' klinisch redeneren. Er worden dan twee tot vijf problemen voorgelegd, die men stap voor stap moet analyseren in interactie met twee docenten, ieder met een specifieke rol. De ene docent is inhoudelijk expert en geeft commentaar op de suggesties van de studenten. De andere docent is voorzitter-discussieleider. De laatste stimuleert de studenten hun antwoorden te motiveren en houdt in de gaten dat alle aspecten van het klinisch redeneren (inclusief (farmaco)therapie) aan bod komen. Hierbij wordt, gezien de groepsgrootte, een vast protocol gehanteerd. 2021

\section{Universiteit van Amsterdam}

De UvA kent sinds 1991 Klinisch Lijnonderwijs (KLO) waarin het klinisch redeneren systematisch aan bod komt. Daarbij is sprake van een programma dat parallel loopt aan de thematische onderwijsblokken in de eerste vier studiejaren voorafgaand aan de co-assistentschappen. Het onderwijs wordt verzorgd in de vorm van grootschalige klinische demonstraties en kleinschalige 'workshops klinische besluitvorming'. In de - interactieve klinische demonstraties staat de werkwijze van de klinische docent centraal. In de 'workshops klinische besluitvorming' leren studenten klinisch redeneren onder leiding van een vaste consulent (klinische docent). Deelname aan deze in totaal circa 34 workshops is verplicht. Elke student is ten minste zeven maal referent en leidt dan de workshop. De gekozen onderwerpen zijn vastgelegd in een blauwdruk en beslaan alle belangrijke klinische problemen die relevant zijn voor de basisarts. Er is geen sprake van een directe koppeling tussen klein- en grootschalig KLO. Behalve het theoretisch KLO kent de UvA ook de vaardigheidslijn van het KLO. Dit bestaat uit practica psychomotorische vaardigheden. Hierin komen vaardigheden aan de orde zoals gesprekstechniek, lichamelijk onderzoek en het hanteren van diagnostische methoden, zoals laboratorium- en röntgenonderzoek. 22

\section{Universiteit Leiden}

De Leidse medische faculteit heeft per september 1999 een curriculumherziening ondergaan. Het oude curriculum bestond uit blokonderwijs en practica. Hierin werd in beperkte mate en op losstaande onderdelen aandacht besteed aan klinisch redeneren.

De curriculumherziening ging gepaard met een inperking van het college-onderwijs en uitbreiding van kleinschalig onderwijs waarin meer aandacht aan klinisch redeneren wordt besteed. In september 1999 is dit gestart voor het eerste studiejaar. Naast de blokken is er lijnonderwijs, waarvoor ongeveer $20 \%$ van de studietijd beschikbaar is. Hierin komt de lijn 'medisch probleemoplossen' aan bod, naast de lijnen 'wetenschappelijke vorming' en 'klinische vaardigheden en attitude'. In de lijn 'medisch probleemoplossen' bestaat het eerste studiejaar uitsluitend uit patiëntendemonstraties die het klinisch denken en handelen van de arts illustreren. In de hogere jaren wordt dit voortgezet met meer aandacht voor het probleemoplossend denken en handelen van de arts. Vanaf jaar 2 zullen studenten in kleine groepen oefenen met behulp van casuïstiek. In jaar 3 en 4 zal dit sterk gekoppeld gaan worden aan zowel 
de communicatieve als de manuele vaardigheden. Wat betreft de keuze van de te behandelen onderwerpen is er op dit moment nog geen definitief overzicht te geven gezien de ontwikkelingsfase waarin dit onderwijs nog verkeert. 2324

\section{Universiteit Maastricht}

In Maastricht komt het klinisch redeneren verspreid in het curriculum impliciet aan bod. Binnen dit probleemgestuurde curriculum wordt voor het grootste deel in kleine onderwijsgroepen gewerkt, waarbij studenten samen 'papieren' problemen trachten op te lossen. Vrijwel elke casusbespreking kan aanzetten tot klinisch redeneren. Vaardigheidstrainingen zijn gericht op het onderzoeken van orgaansystemen, waarbij in het eerste en tweede studiejaar de nadruk ligt op de techniek en systematiek van het onderzoek. In het derde en vierde studiejaar is er veel aandacht voor mogelijke afwijkende bevindingen en de klinische relevantie daarvan. Tijdens het practicum pathologie wordt aandacht besteed aan de rol van pathofysiologische processen bij ziektegeschiedenissen en wordt dit systematisch in kleine groepen studenten besproken. Een adoptieprogramma huisartsgeneeskunde besteedt aandacht aan 'diagnostisch redeneren'. Dit wordt geoefend aan de hand van gerichte opdrachten. In simulatiepatiëntencontacten wordt tijdens de eerste vier studiejaren geoefend in consultvoering, waarbij klinisch redeneren aan bod komt.

Binnen de zogenaamde klinische onderwijsgroepen wordt expliciete aandacht gegeven aan het klinisch redeneren. Dit zijn negen bijeenkomsten in het vierde jaar op afdelingen in het ziekenhuis, waarbij enerzijds geleerde vaardigheden en theoretische kennis geïntegreerd worden en anderzijds inzicht moet worden verkregen in het proces van diagnostisch redeneren aan de hand van doorgaans poliklinische patiënten. Het gestructureerd, "hypothesegestuurd' verrichten van de anamnese en in mindere mate ook het lichamelijk onderzoek, komen aan bod. Integratie van pathofysiologische kennis in centrale klinische concepten speelt een belangrijke rol. Studenten moeten klachten en symptomen van patiënten vanuit de pathofysiologie kunnen verklaren. Deze kleine groepen worden begeleid door klinische docenten. ${ }^{25} 26$ Gezien de verspreide programmering is er geen sprake van een vooraf gemaakte blauwdruk van te behandelen onderwerpen. Niettemin lijkt het er wel op dat de belangrijkste klinische problemen aan bod kunnen komen.

\section{Universiteit Utrecht}

Het oude curriculum geneeskunde in Utrecht was traditioneel van opzet en kende een sterk biomedisch profiel. In 1997 werd een begin gemaakt met vakoverstijgend en meer klachtgericht onderwijs in de vorm van Klinisch Lijnonderwijs (KLO) voor het tweede, derde en vierde studiejaar waaraan alle klinische vakgroepen deelnemen. Per studiejaar worden zes thema's behandeld. Per thema bereiden studenten, na een inleidend college, zich door middel van zelfstudie voor op een bijeenkomst in kleine groepen onder leiding van twee referentstudenten. Tijdens de bijeenkomst wordt een patiëntenprobleem van diagnostiek tot en met therapie besproken. Alle interventies van de arts worden gewogen en beoordeeld. Een clinicus is aanwezig en fungeert als consulent. In een afsluitend college wordt het thema afgerond. Naast deze onderwijsvorm wordt tijdens de blokken inwendige geneeskunde I en II (studiejaar 3 en 4) aandacht besteed aan het uitvragen van 'grote interne beelden' bij een (simulatie)patiënt en aan de opbouw van een diagnose en therapie naar aanleiding van klinische besprekingen van patiënten. ${ }^{27}$ 
In september 1999 is het nieuwe curriculum (CRU'99) gestart. Er is geen inleidend college meer, maar er is een uitgebreid handboek voorzien van casus. In het eerste jaar wordt van september tot december begonnen met enkele klinische demonstraties die, in aanwezigheid van een patiënt, het klinisch redeneren duidelijk maken. Kleinschalige KLO-bijeenkomsten beginnen in de tweede helft van het eerste jaar en gaan door in het tweede jaar. Ook daarvoor is een uitgebreid casusboek voorhanden. De onderwerpen zijn zodanig gekozen en vastgelegd dat er een spreiding ontstaat over diverse klinische deelgebieden en aansluiting op voorafgaande blokken gegarandeerd is. De groepen worden begeleid door één of twee vaste klinische docenten (consulenten). Bij toerbeurt vervullen drie studenten de rol van 'referent'. Tijdens het Klinisch Lijn Theater (KLT) wordt op grootschalige wijze (patiëntendemonstratie in collegezaal) het denkproces van de dokter gedemonstreerd. In het derde, vierde en vijfde studiejaar worden er op systematische wijze casus besproken waarbij de prekliniek weer terugkomt in de kliniek. Dit onderwijs loopt parallel aan de co-assistentschappen, die reeds in het derde jaar beginnen. De student wordt gevraagd om de preklinische aspecten (bijvoorbeeld basale pathofysiologische concepten) van de casus nog eens te herhalen en eventueel te verdiepen. Dit onderwijs is Theoretisch Lijnonderwijs (TLO) genoemd. $28-30$

\section{Vrije Universiteit Amsterdam}

Sinds 1991 bestaat aan de VU het Klinisch Lijnonderwijs (KLO), parallel geprogrammeerd aan het blokonderwijs, waarin het klinisch redeneren centraal staat. In het propedeusejaar heeft het KLO de functie van illustratie van, en kennismaking met het geneeskundig handelen. In de drie doctoraaljaren ligt de nadruk op het zelf oefenen met casuïstiek, waarin het klinisch denken en handelen centraal staan. De toe- passing van medische kennis (verkregen in het blokonderwijs) en redeneervaardigheden aan de hand van individuele klinische situaties wordt in verplichte werkgroepen onder begeleiding van een clinicus, en in peergroepen onder leiding van een ouderejaarsstudent geoefend (kleinschalig KLO). ${ }^{31}$ Tijdens patiëntendemonstraties in collegevorm (grootschalig KLO) komen deze klinische situaties op interactieve wijze weer aan de orde en wordt het klinisch redeneren gedemonstreerd. Daarnaast wordt teruggekomen op de problemen en/of vragen die in de werkgroepen naar voren gekomen zijn. Er zijn 20 werkgroepbijeenkomsten en 35 peergroepbijeenkomsten in het doctoraalprogramma. Elk jaar heeft zijn eigen accenten: in het tweede jaar is dat de hypothesevorming, toetsing met behulp van de anamnese en lichamelijk onderzoek, en differentiaaldiagnostiek; in het derde jaar de aanvullende diagnostiek en in het vierde jaar de therapie. De te behandelen klinische problemen zijn vastgelegd (aanvankelijk in een blauwdruk en later op basis van Raamplan 1994) en beslaan de belangrijke problemen voor de aanstaande basisarts. In 1997 is het KLO aan de VU in het kader van een onderwijskwaliteitsfondsproject geprofessionaliseerd: docenten werden getraind in het maken van goed onderwijsmateriaal ten behoeve van het klinisch redeneren. Daarnaast krijgt binnen het KLO de farmacotherapie sinds 1998 in alle doctoraaljaren expliciete aandacht, waarbij studenten aan de hand van casuïstiek oefenen in kleine groepen, deels met simulatiepatiënten. Aan de hand van directe observaties en via recapitulatiecolleges wordt feedback gegeven. Studenten ontwikkelen tijdens dit onderwijs een eigen formularium, dat in de co-assistentschappen verder gebruikt wordt. ${ }^{32-34}$

Tabel 1 geeft een vergelijkend overzicht inzake het onderwijs klinisch redeneren aan de acht medische faculteiten. 


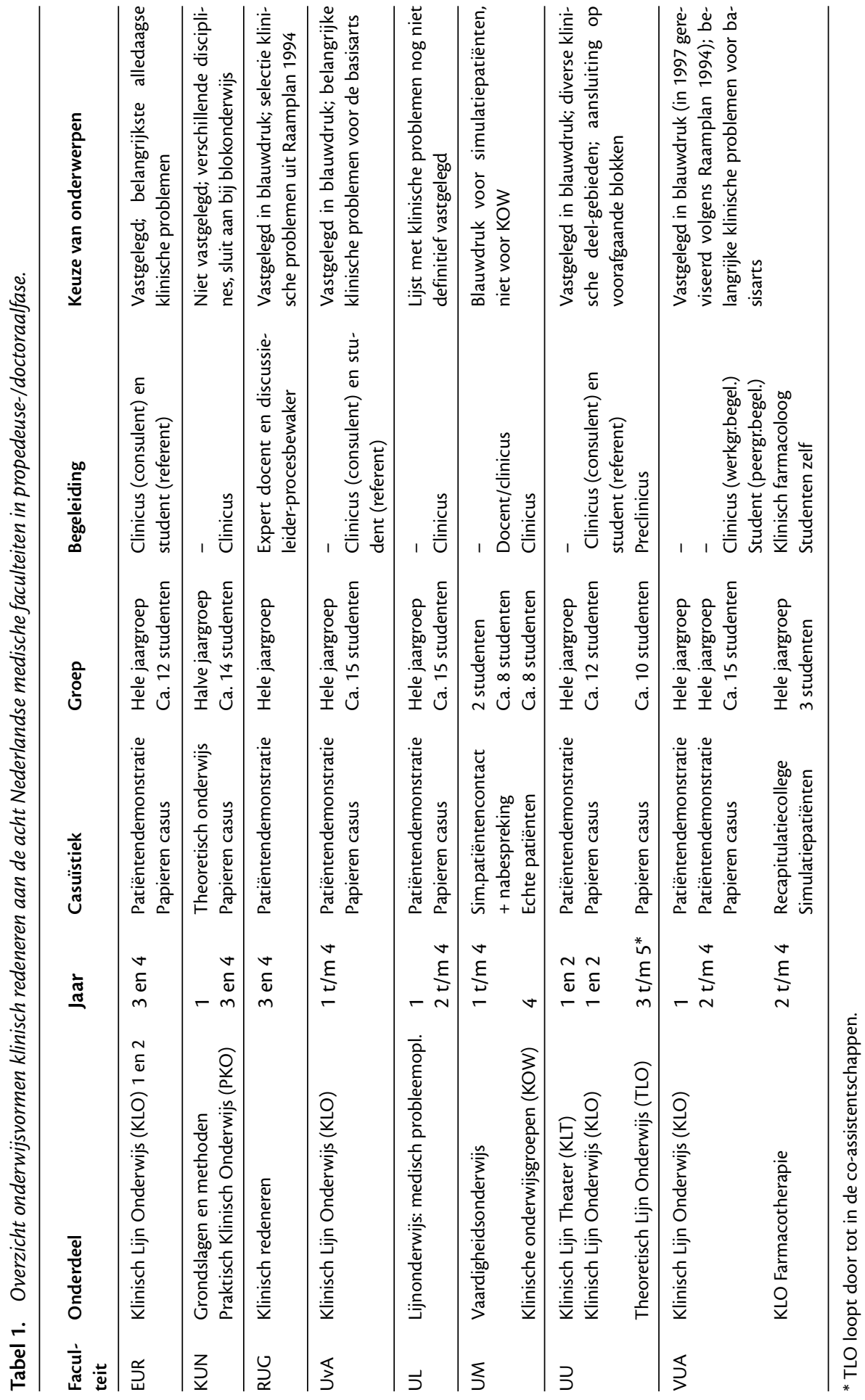




\section{Beschouwing}

Er wordt een grote diversiteit gezien in de mate van ontwikkeling van het onderwijs in klinisch redeneren. Zo kennen de Erasmus Universiteit Rotterdam (EUR) en de Universiteit Leiden (UL) een nog relatief klein programma dat in ontwikkeling is, terwijl de Universiteit van Amsterdam (UvA) en de VU Amsterdam (VUA) een al langer bestaande, uitgekristalliseerde onderwijslijn KLO hebben. Bijna alle universiteiten hebben een onderwijsprogramma klinisch redeneren dat zich uitstrekt over alle studiejaren. Alleen aan de Katholieke Universiteit Nijmegen (KUN) en de Rijksuniversiteit Groningen (RUG) is dat niet het geval. De nieuwe programma's van de EUR en de Universiteit Utrecht (UU) lijken qua opzet sterk op dat van de UvA. De Universiteit Maastricht (UM), RUG, KUN, en VUA hebben elk een eigen, duidelijk herkenbaar, programma. De gehanteerde onderwijsvormen en methodieken verschillen. Zo kunnen studenten in het onderwijs in kleine groepen begeleid worden door (pre-)klinische docenten (alle universiteiten), maar ook door (ouderejaars)studenten (VUA). Ook kunnen groepsleden als 'referent' fungeren (UU, UvA). Binnen de kleine groepen staat overal de papieren casus centraal; alleen de UM werkt hier met simulatiepatiënten of zelfs echte patiënten. De omvang van de groepen varieert van acht tot achttien studenten. Waar het optimum ligt is onbekend. Voordelen van een heel kleine groep kunnen zijn veiligheid en het voldoende aan bod kunnen komen van alle groepsleden; nadeel kan zijn dat er onvoldoende diversiteit van meningen en visies is. In te grote groepen is dit juist andersom. Ervaringen aan de VUA leren ons dat in groepen van meer dan vijftien personen het redeneren niet goed meer uit de verf komt.
In het grootschalige onderwijs (niet aan de KUN en UM) vinden colleges met of zonder patiënten plaats, waarbij al dan niet mono- of multidisciplinair gewerkt wordt. Soms wordt in dit onderwijs teruggekoppeld naar de werkgroepen (RUG, VUA), vaak ook niet (UU, UvA). De opbouw van het onderwijs in klinisch redeneren tijdens de eerste vier studiejaren verschilt sterk per universiteit, waarbij centraal staat 'wanneer' men studenten met 'welke (hoeveelheid) kennis' patiëntenproblemen laat oplossen. Het is nog onduidelijk of verschillen in (het gebruik van) achterliggende theorieën over leren klinisch redeneren een rol spelen in de onderwijspraktijk in Nederland.

Wat betreft de keuze van de te behandelen klinische problemen is het opvallend dat de meeste universiteiten de belangrijkste klinische problemen vanuit de verschillende disciplines aan bod laten komen, hetgeen aansluit bij de gedachte dat inhoudsspecificiteit bij klinisch redeneren sterk geldt. Vaak is er zelfs een blauwdruk van de onderwerpen, al dan niet gerelateerd aan het Raamplan 1994, beschikbaar. Alleen de KUN en de UM beschikken niet over een vastgelegde onderwerpenlijst.

Het is niet mogelijk per faculteit een exact overzicht te geven van de onderwijstijd die werkelijk besteed wordt aan klinisch redeneren. Binnen de diverse onderwijsprogramma's worden studenten geacht, naast de contacturen, veel zelfstudie-uren te besteden aan dit onderwijs. Hoeveel uren dat zijn, zal per student sterk variëren.

Interessant is de vraag welke ontwikkeling in de toekomst gewenst is. Moeten de universiteiten streven naar een consensus als het gaat over een theoretisch en onderwijskundig model klinisch redeneren? En waarop zou deze keuze dan gebaseerd moeten zijn? Een eerste initiatief in deze 
richting is reeds vanuit de acht afdelingen basisonderwijs huisartsgeneeskunde ontstaan met het verschijnen van het leerboek 'Het geneeskundig proces', waarin het diagnostisch proces van klacht tot en met therapie aan de orde komt. ${ }^{35}$ Inmiddels gebruiken deze afdelingen dit boek bij het onderwijs huisartsgeneeskundig klinisch redeneren.

Daarnaast is er de vraag welke plaats klinisch redeneren in een onderwijscurriculum zou moeten hebben, naast biomedisch, vaardigheden- en attitudeonderwijs. Een probleem daarbij is, dat er vroeg in de studie slechts in beperkte mate klinisch redeneren mogelijk is, omdat bepaalde kennis nog ontbreekt. De in deze fase behandelde problemen zouden idealiter, als herhaling, later in de studie moeten terugkomen wanneer de kennis toegenomen is.

Definitieve antwoorden op deze vragen kunnen pas gegeven worden na verdere analyse en evaluatie van de in gang gezette (vernieuwde) onderwijsprogramma's. Wij pleiten voor de ontwikkeling van een breed gedragen en geaccepteerd Nederlands theoretisch model klinisch redeneren. Een gezamenlijke aanpak van de faculteiten daarbij zou wenselijk zijn, bijvoorbeeld door middel van het formuleren van een minimumpakket van voorwaarden voor onderwijs in klinisch redeneren, het informeren over elkaars onderwijsprogramma's en onderwijsmateriaal, en het uitwisselen van toetsvragen.

Dank gaat uit naar dr. A.H. Bootsma (EUR), prof. dr. Th.J. ten Cate (UU), drs. H.L. Hendrix (UL), dr. C.T. Postma (KUN), dr. K. Reenders (RUG), prof. dr. H.J.M. van Rossum (RUG, vanaf 1.9.01 VUA), dr. N.C. Schaper (UM), dr. G.W. Spaai (EUR), drs. M. Teunisse (UvA), prof. dr. Th.Voorn (UU) en prof. dr. P. de
Vries Robbé (KUN) voor het verifiëren en aanleveren van gegevens en/of hun kritisch commentaar bij de totstandkoming van dit artikel.

\section{Literatuur}

1. Patel VL, Kaufman DR. Clinical reasoning and biomedical knowledge: implications for teaching. In: Clinical reasoning in the health professions. Oxford; 1995. p. 117-128.

2. Metz JCM, Pels Rijcken-van Erp Taalman Kip EH, Brand-Valkenburg BWM van den. Raamplan 1994 artsopleiding, eindtermen van de artsopleiding. Nijmegen: Universitair Publikatiebureau Katholieke Universiteit Nijmegen; 1994.

3. Metz JCM, Verbeek-Weel AMM, Huisjes HJ. Raamplan 2001: bijgestelde eindtermen van de artsopleiding. Nijmegen: Mediagroep; 2001.

4. Neufeld VR, Norman GR, Feightner JW, Barrows H. Clinical problem-solving by medical students: a cross-sectional and longitudinal analysis. Med Educ 1981;15(5):315-21.

5. Lewkonia RM, Harasym PH, Darwish HZ. Early introduction to medical problem-solving. Med Teach 1993;15(1):57-65.

6. Donelly MB, Sisson JC, Woolliscroft JO. The reliability of a hypothesis generation and testing task. Med Educ 1990;24(6):507-11.

7. Elstein AS, Shulman LS, Sprafka SA. Medical problem solving. An analysis of clinical reasoning. Cambridge, MA/London, U.K.: Harvard University Press; 1978.

8. Mandin H, Jones A, Woloschuk W, Harasym P. Helping students learn to think like experts when solving clinical problems. Acad Med 1997;72:173-9.

9. Norman GR. The epistemology of clinical reasoning: perspectives from philosophy, psychology and neuroscience. Acad Med 2000;75(suppl.):12733.

10. Custers EFJM, Stuyt PMJ, Vries Robbé PF de. Clinical problem analysis (CPA): a systematic approach to teaching complex medical problem solving. Acad Med 2000;75:291-7.

11. Studiegids Geneeskunde en Gezondheidswetenschappen. Rotterdam: Erasmus Universiteit Rotterdam; 1999.

12. Pols HAP, Bootsma AH, Spaai GWG. Handleiding Medisch Probleemoplossend Onderwijs. Studiejaar 1998-1999. Rotterdam: Faculteit Geneeskunde en Gezondheidswetenschappen, Erasmus Universiteit Rotterdam; 1998.

13. Holdrinet RSG, Oeseburg B, Bulte JA, Leunissen RRM. Kerndoelstellingen tot het doctoraal geneeskunde. In: Cate ThJ ten, Dikkers JH, Houtkoop E, Pollemans MC, Pols J, Smal JA, redactie. Gezond Onderwijs 5. Houten/Zaventem: Bohn Stafleu Van Loghum; 1996: p. 161-166. 
14. Holdrinet RSG, Oeseburg B, Bulte JA. Het ontwerp van het nieuwe Nijmeegse curriculum geneeskunde. In: Smal JA, Cate ThJ ten, Denekens J, Dikkers JH, Remmen R, Spaai GWG, Verweij AMJJ, redactie. Gezond Onderwijs 6. Houten/Diegem: Bohn Stafleu Van Loghum; 1997. p. 104-108.

15. Postma CT, redactie. Blokboek Praktisch Klinisch Onderwijs 2. Nijmegen: Uitgave Faculteit der Medische Wetenschappen, Katholieke Universiteit Nijmegen; september 2000.

16. Jacobs JCG, Cools BM, Postma CT. Klinische probleemanalyse als methodiek in het onderwijs in probleemoplossingsvaardigheden in het $\mathrm{Nij}$ meegse geneeskundecurriculum. Tijdschrift voor Medisch Onderwijs 2002;21(2):64-74.

17. Studiegids Faculteit der Medische Wetenschappen. Geneeskunde. Nijmegen: Katholieke Universiteit Nijmegen; 1999-2000.

18. Cohen-Schotanus J. Van een traditioneel naar een patiëntgeoriënteerd curriculum: ander studeergedrag? In: Cate ThJ ten, Dikkers JH, Houtkoop E, Pollemans MC, Pols J, Smal JA, redactie. Gezond Onderwijs 5. Houten/Zaventem: Bohn Stafleu Van Loghum; 1996. p 89-94.

19. Rossum HJM van. Voortgangsrapportage over de eerste versie van programma 'Klinisch Redeneren' in jaar 3 en 4 van Curriculum 2000. Groningen; 1997.

20. Studiegids Faculteit der Medische Wetenschappen Groningen. Groningen: Rijksuniversiteit Groningen; 1999.

21. Minnen B van, Rossum HJM van. Klinisch redeneren met grote groepen, kan dat? In: Smal JA, Cate ThJ ten, Denekens J, Dikkers JH, Remmen R, Spaai GWG, Verweij AMJJ, redactie. Gezond Onderwijs 6. Houten/Diegem: Bohn Stafleu Van Loghum; 1997. p. 180-184.

22. Cate ThJ ten. Kleinschalig theoretisch klinisch lijnonderwijs. Ned Tijdschr Geneeskd 1994;138(24): 1238-42.

23. Studiegids Faculteit der Geneeskunde Leiden. Universiteit Leiden; 1997.

24. Ruijven AGH van, Hendrix HL. Curriculumherziening in sneltreinvaart. Abstract en voordracht Gezond Onderwijs Congres, Veldhoven, 1999.

25. Bokhoven MA van, Dalen J van, Verheggen $\mathbf{M}$, Verhoeven BH, Verwijnen GM. Curriculum geneeskunde Maastricht. Waar komt klinisch redeneren (idealiter) aan de orde? Inventarisatie ten behoeve van de cursus SMO 7, 1998.

26. Oosterof I, Grave WS de, Dolmans DHJM, Schaper $\mathrm{NC}$, Vleuten CPM van der. De ontwikkeling van een instrument om het functioneren van begeleiders van de klinische onderwijsgroep te meten. Tijdschrift voor Medisch Onderwijs 2002;21(3): -.

27. Studiegids Geneeskunde 1997-1998. Universiteit Utrecht; 1997.

28. Borleffs JCC, Mulder H, Smal JA. CRU'99: uitgangspunten en karakteristieken. Tijdschrift voor Medisch Onderwijs 2001;20(Supplement):S7S10.

29. Rutten GEHM, Borleffs JCC, Cate ThJ ten. Onderdelen van CRU'99. Klinisch Lijn Onderwijs. Tijdschrift voor Medisch Onderwijs 2001;20 (Supplement):S30-S31.

30. Westerveld HE, Jongsma HJ. Onderdelen van CRU'99. Theoretisch Lijn Onderwijs. Tijdschrift voor Medisch Onderwijs 2001;20(Supplement): S32-S34.

31. Gercama AJ, Tieleman D, Retel Helmrich, Bastiaans JF. Resultaten van training en begeleiding van student-docenten in het klinisch lijnonderwijs. Tijdschrift voor Medisch Onderwijs 2001;20(3):114-23.

32. Gercama AJ. Methodiek van het Klinisch Lijnonderwijs; stellingen, verantwoording en uitwerking. Notitie centrale commissie KLO-VU; 1996.

33. Bastiaans JF, Huinink S, Ittersum FJ van, Sagasser MH. Klinisch Probleemoplossen in de praktijk. Rapport Onderwijs Kwaliteitsfonds. Vrije Universiteit Amsterdam; 1998.

34. Bastiaans JF, Ittersum FJ van, Huinink S, Sagasser MH, Gercama AJ, Haan M de. Zeven jaar klinisch lijnonderwijs aan de Vrije Universiteit: de problemen, de docententraining en het onderwijsmateriaal. Tijdschrift voor Medisch Onderwijs 2000;19(6):218-24.

35. Grundmeijer HGLM, Reenders K, Rutten GEHM, redactie. Het geneeskundig proces, van klacht naar therapie. Maarssen: Elsevier/Bunge; 1999.

De auteurs:

J.F.Bastiaans, huisarts/universitair docent, afdeling huisartsgeneeskunde VUmc.

$H$. de Vries, huisarts/universitair hoofddocent/coördinator, afdeling huisartsgeneeskunde VUmc.

M. de Haan, huisarts/hoogleraar huisartsgeneeskunde, afdeling huisartsgeneeskunde VUmc.

Alle auteurs zijn verbonden aan het Vrije Universiteit medisch centrum te Amsterdam.

\section{Correspondentieadres:}

J.F. Bastiaans, Afdeling Huisartsgeneeskunde Vrije Universiteit medisch centrum, Van der Boechorststraat 7, 1081 BT Amsterdam, jf.bastiaans.gpnh@med.vu.nl. 


\section{Summary}

Introduction: The eight Dutch Medical Schools are placing increasing importance on the teaching of clinical reasoning skills. This article presents a definition of (the teaching of) clinical reasoning and uses that definition to describe the parts of the Dutch undergraduate teaching programmes that can be labelled as courses in clinical reasoning.

Method: A document analysis of the schools' educational programmes, teaching materials and publications formed the basis for a description of each school's clinical reasoning programme. Each description was checked by an expert from that school.

Results: The programmes on clinical reasoning are very diverse regarding both development and extent. Different teaching formats and methods are used. Large group teaching concerns mostly lectures, which may or may not involve real patients. Small group teaching uses mostly paper patient cases, although Nijmegen and Maastricht also use real and/or standardised patients. Group sizes differ and the teachers/moderators vary from clinicians, other faculty, senior students or peers. The content of most programmes is determined by a blueprint - in some cases derived from Blueprint 1994.

Discussion: The current curriculum revisions will bring changes to the teaching of clinical reasoning. An interesting question is whether medical schools might benefit from collaborating to develop a common theoretical and edcucational model for the teaching of clinical reasoning skills. Another important consideration is timing: how early in the curriculum can clinical reasoning courses be effective. Careful programme evaluation and exchange of information about programmes, teaching materials and test formats and items can contribute to the development of a solid educational programme on clinical reasoning. (Bastiaans JF, Vries $H$ de, Haan M de. Clinical reasoning in the educational programmes of the Dutch Medical Schools. Dutch Journal of Medical Education 2002;21(3): 111-121.) 